\title{
Identification of a parasitic symbiosis between respiratory metabolisms in the biogeochemical chlorine cycle
}

\author{
Tyler P. Barnum ${ }^{1} \cdot$ Yiwei Cheng ${ }^{2} \cdot$ Kaisle A. Hill $\mathbb{1}^{1} \cdot$ Lauren N. Lucas $^{1} \cdot$ Hans K. Carlson ${ }^{3} \cdot$ John D. Coates ${ }^{1}$
}

Received: 23 September 2019 / Revised: 8 January 2020 / Accepted: 23 January 2020 / Published online: 5 February 2020

(c) The Author(s), under exclusive licence to International Society for Microbial Ecology 2020

\begin{abstract}
A key step in the chlorine cycle is the reduction of perchlorate $\left(\mathrm{ClO}_{4}^{-}\right)$and chlorate $\left(\mathrm{ClO}_{3}{ }^{-}\right)$to chloride by microbial respiratory pathways. Perchlorate-reducing bacteria and chlorate-reducing bacteria differ in that the latter cannot use perchlorate, the most oxidized chlorine compound. However, a recent study identified a bacterium with the chlorate reduction pathway dominating a community provided only perchlorate. Here we confirm a metabolic interaction between perchlorate- and chlorate-reducing bacteria and define its mechanism. Perchlorate-reducing bacteria supported the growth of chlorate-reducing bacteria to up to $90 \%$ of total cells in communities and co-cultures. Chlorate-reducing bacteria required the gene for chlorate reductase to grow in co-culture with perchlorate-reducing bacteria, demonstrating that chlorate is responsible for the interaction, not the subsequent intermediates chlorite and oxygen. Modeling of the interaction suggested that cells specialized for chlorate reduction have a competitive advantage for consuming chlorate produced from perchlorate, especially at high concentrations of perchlorate, because perchlorate and chlorate compete for a single enzyme in perchlorate-reducing cells. We conclude that perchlorate-reducing bacteria inadvertently support large populations of chlorate-reducing bacteria in a parasitic relationship through the release of the intermediate chlorate. An implication of these findings is that undetected chlorate-reducing bacteria have likely negatively impacted efforts to bioremediate perchlorate pollution for decades.
\end{abstract}

\section{Introduction}

The chlorine cycle consists of the biological, geological, and chemical processes that interconvert organic and inorganic chlorine compounds [1]. Chlorine oxyanions are a group of inorganic chlorine compounds of particular interest in biology due to their high reduction potentials

Supplementary information The online version of this article (https:// doi.org/10.1038/s41396-020-0599-1) contains supplementary material, which is available to authorized users.

$\triangle$ John D. Coates

jdcoates@berkeley.edu

1 Department of Plant and Microbial Biology, University of California, Berkeley, CA 94720, USA

2 Climate and Ecosystem Sciences Division, Lawrence Berkeley National Laboratory, Berkeley, CA 94720, USA

3 Environmental Genomics and Systems Biology Division, Lawrence Berkeley National Laboratory, Berkeley, CA 94720, USA
$\left(E^{0^{\prime}}>0.7 \mathrm{~V}\right)$ [2-5]. Hypochlorite $\left(\mathrm{ClO}^{-}\right)$and chlorite $\left(\mathrm{ClO}_{2}^{-}\right)$are highly reactive compounds that damage cells through oxidative chemistry [6-8], while chlorate $\left(\mathrm{ClO}_{3}{ }^{-}\right)$ and perchlorate $\left(\mathrm{ClO}_{4}^{-}\right)$are used as electron acceptors in respiration by some bacteria and archaea [5]. Uniquely among chlorine oxyanions, perchlorate is chemically stable in solution, and a necessary step in the chlorine cycle is the reduction of perchlorate to chloride by microbial respiration [5, 9]. Where this microbial activity is absent, geochemical reactions in the atmosphere lead to the accumulation of perchlorate and, to a lesser degree, chlorate $[5,10,11]$. Both atmospheric deposition of chlorine oxyanions and microorganisms respiring chlorine oxyanions appear to be widespread $[12,13]$, yet the biogeochemistry of this key part of the chlorine cycle is not well understood [5].

An important unresolved question is whether the microbial respiration of chlorine oxyanions in the environment is performed by individual cells or by groups of cells with different parts of the biochemical pathway [14, 15]. Many redox metabolisms from other elemental cycles have been found to occur through pathways that can be divided between different cells, including nitrate reduction [16]; ammonia oxidation 
A. $\mathrm{ClO}_{x}$-reduction pathways

Perchlorate $\left(\mathrm{ClO}_{4}^{-}\right) \quad$ Chlorate $\left(\mathrm{ClO}_{3}^{-}\right)$ reduction reduction

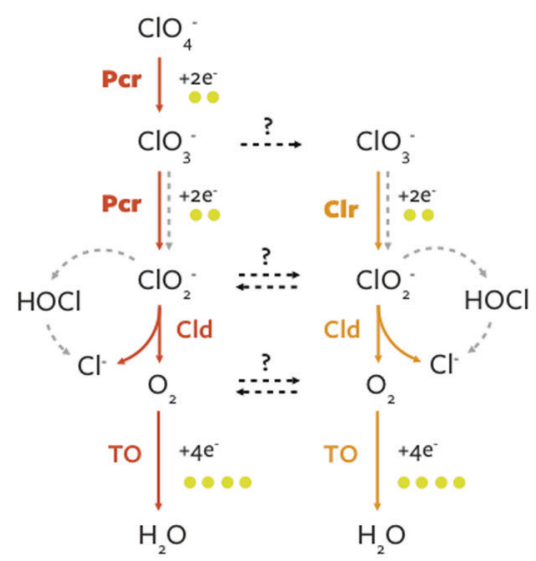

\section{Hidden colony-forming units} Perchlorate (10x) Chlorate

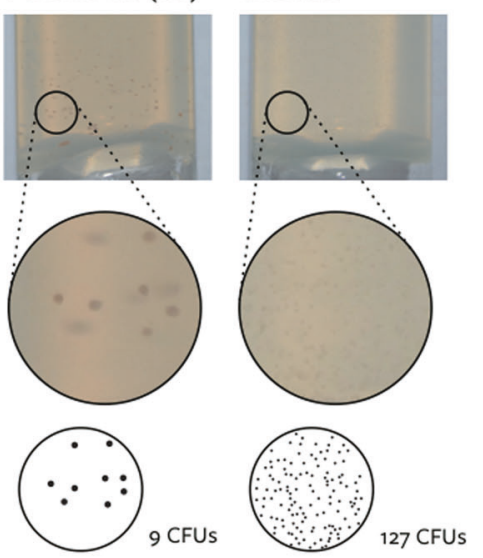

B. Perchlorate-reducing cultures Culture Genome/MAG
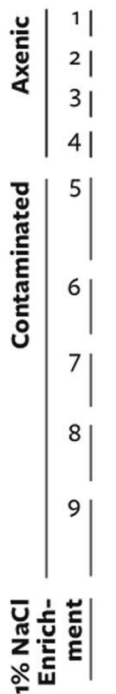

D. Chlorate-reducing isolates

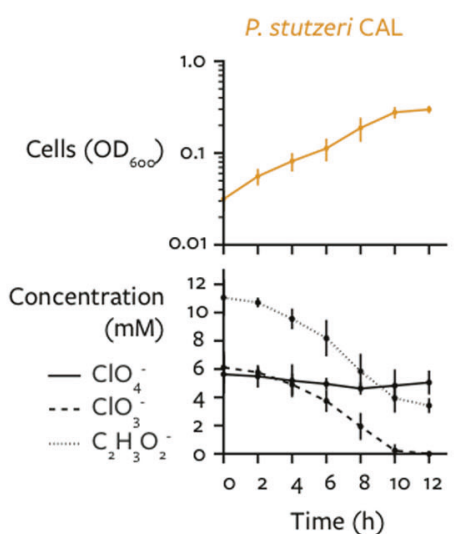

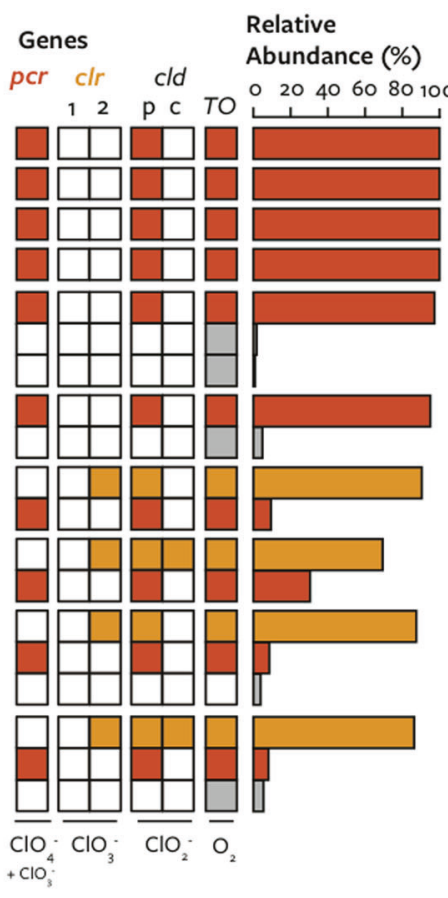

Compl.

(\%)

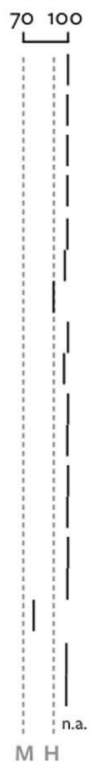

Fig. 1 Isolation of chlorate-reducing bacteria from perchloratereducing cultures. a Pathways for the respiration of perchlorate (red) and chlorate (orange) involve the enzymes perchlorate reductase (Pcr) or chlorate reductase $(\mathrm{Clr})$, chlorite dismutase $(\mathrm{Cld})$, and a terminal oxidase reducing oxygen to water (TO). b Binning and key genes of genomes from perchlorate-reducing cultures. A previously sequenced perchlorate-reducing enrichment is included for comparison (" $1 \%$ $\mathrm{NaCl}$ Enrichment"). Filled squares indicate gene presence. Relative abundance $(\%)$ was calculated as normalized coverage divided by total

$[17,18]$; sulfur oxidation and reduction [19, 20]; and organic chlorine reduction [21]. Complete pathways might even be rare in environmental systems: a recent description of metagenome-assembled genomes from aquifer sediment found that only a minority of organisms with genes for nitrate reduction or sulfur oxidation had the complete pathway [22]. In many cases, respiratory metabolisms have been observed to involve both cells with complete pathways and cells with partial pathways, a form of symbiosis that can range from mutualistic to antagonistic [23-26]. coverage for all genomes. Compl. (\%) refers to percent completeness (single copy genes); dashed lines indicate medium quality (M) and high quality $(\mathrm{H})$ completeness. All genomes had negligible contamination $(<3 \%)$. c Magnified image of colonies that developed in agar media supplied perchlorate or chlorate from a co-culture of Denitromonas halophilus SFB-1 and Pseudomonas stutzeri CAL. The inoculum for perchlorate agar media was ten-times more concentrated. d Dissimilatory reduction of chlorate and not perchlorate by isolated chlorate-reducing bacteria.

Chlorate reduction could be considered a partial pathway of perchlorate reduction, as the two pathways share substantial similarities [5]. The key difference is whether or not the initial step of the pathway is catalyzed by a perchlorate reductase $(\mathrm{Pcr})$, which reduces both perchlorate and chlorate, or by a chlorate reductase (Clr), which can only reduce chlorate (Fig. 1a) [27]. Both metabolisms occur in the bacterial periplasm, where perchlorate and/or chlorate are reduced to chlorite, chlorite is converted to chloride and oxygen by a chlorite dismutase (Cld) [12, 28-30], and 
oxygen is reduced to water by one or more terminal oxidases [14, 31, 32]. Energy is conserved by the reduction of perchlorate, chlorate, and oxygen but not in the conversion of chlorite to oxygen and chloride (Fig. 1a) [33]. Genes for these enzymes are found together within horizontally transferred genomic DNA or plasmid DNA, typically with accessory genes for signaling and regulation, reactive chlorine stress response, protein and cofactor assembly, and genetic mobility [11, 34, 35]. Some bacteria and archaea have been experimentally observed or engineered to reduce perchlorate or chlorate to chlorite, relying on a second organism or chemical reactions to remove chlorite [14, 36-38]. However, selection for perchlorate- or chloratereducing microorganisms from the environment has only yielded bacteria with the canonical pathways described above [5, 15].

Though the pathways for chlorine oxyanion respiration have been studied in parallel for decades [33, 39], research on interactions between them is sparse. One set of studies explored how unusually high accumulation of chlorate by the perchlorate-reducing bacterium Dechlorosoma sp. HCAP-C (PCC) could support chlorate-reducing bacteria [40-42]. Addition of a chlorate-reducing bacterium in coculture with strain HCAP-C decreased the concentration of chlorate, and while models of the system suggested growth of the chlorate-reducing bacterium, the community structure in situ was not determined [40, 42]. Accumulation of chlorate by strain HCAP-C was proposed to occur because a single enzyme (Pcr) catalyzes two sequential reactions in the pathway (reduction of perchlorate to chlorate, and chlorate to chlorite) [41, 43]. As that trait is shared by all known perchlorate-reducing bacteria, and several perchlorate-reducing bacteria have been reported to accumulate chlorate, albeit at much lower concentrations [44-46], it was speculated that chlorate-reducing bacteria may be a common feature of natural perchlorate-reducing communities [42, 43].

No subsequent research examined the possibility of interaction between chlorine oxyanion reduction pathways in communities until recently, when we observed a genome with chlorate reduction genes in a perchlorate-enriched community [15]. Surprisingly, the putative chloratereducing population was tenfold more abundant than the perchlorate-reducing population. Because no chlorate had been added to the cultures, the chlorate-reducing population either had unknown perchlorate reduction genes or was metabolizing intermediates of the perchlorate reduction pathway [15].

In the present study, we investigate the interaction between perchlorate-reducing bacteria and chloratereducing bacteria. After sequencing the genomes of perchlorate-reducing cultures obtained from estuary sediment enrichments [47], we detected contaminating bacteria that had not been completely removed during isolation. We discovered that several cultures were not predominantly perchlorate-reducing bacteria, as expected, but dominated by chlorate-reducing bacteria. We therefore used a combination of co-cultures, genetics, and modeling to confirm the interaction, define its mechanism, and explain how such a community structure could be produced. We conclude that the environmental chlorine cycle involves the interaction of a complete pathway and a partial pathway in the reduction of perchlorate to chloride.

\section{Materials and methods}

\section{Genome sequencing, assembly, binning, and annotation}

Genomic DNA was extracted using a MoBio PowerSoil DNA Extraction Kit with a cell lysis protocol consisting of vortexing and heating at $70{ }^{\circ} \mathrm{C}$ for $5 \mathrm{~min}$, repeated twice (MoBio Laboratories, Inc., Carlsbad, CA). DNA library preparation and DNA sequencing were performed by the Adam Arkin Laboratory or the Vincent J. Coates Genomics Sequencing Laboratory at the California Institute of Quantitative Biosciences (QB3, Berkeley, CA) using an Illumina MiSeq V2 (150PE or 250PE) and Illumina Hiseq4000 (100PE), respectively. Paired-end reads from each sample were trimmed using Sickle v. 1.33 with default parameters [48], error-corrected using SGA v. 0.10 .15 [49], and assembled using MEGAHIT v. 1.1.2 with the parameters --no-mercy and --min-count 3 [50]. After assembly, reads were mapped back to each assembly using the BurrowsWheeler Alignment Tool v. 0.7.10 (BWA) BWA-MEM algorithm [51]. All manipulation of reads was performed on high-performance computing clusters administered by the Computational Genomics Resource Laboratory (CGRL).

Genome assemblies were screened for contamination using Anvi'o v. 3.1 [52]. Briefly, contigs $>2000$ bp were manually binned into genomes using the hierarchical clustering generated from sequence characteristics and read coverage. When multiple genomes were present in a single assembly, contigs were binned into metagenome-assembled genomes (MAGs). Because perchlorate and chlorate respirations involve horizontally transferred genes that are subject to poor assembly, the BLAST feature in Bandage $\mathrm{v}$. 0.8.0 [53] was used to identify key genes and confirm their presence and absence in genomes as previously described [15]. The completeness and contamination of each genome and metagenome-assembled genome was measured using CheckM [54], which measures the single copy genes expected within a lineage and defines contamination as redundant genes with $<90 \%$ amino acid identity. Gene prediction and annotation was performed using Prokka v. 
1.11 [55], and key genes were identified using custom profile Hidden Markov models (HMMs) trained on previously confirmed proteins using HMMER v. 3.1b2 [56]. All reads and genome sequences are available through the NCBI Bioproject accession PRJNA387015 [15].

\section{Strains, media, and culture conditions}

A complete set of strains and cultivation conditions are included in Supplementary Table 1. Growth medium for perchlorate-reducing cultures consisted of either a freshwater defined medium [12] or a marine defined medium [57] at $\mathrm{pH} 7.2$ with, unless noted otherwise, $10 \mathrm{mM}$ acetate as the electron donor and carbon source and $10 \mathrm{mM}$ perchlorate as the electron acceptor. All media and stocks were made anoxic by sparging with $\mathrm{N}_{2}$. Growth experiments were performed at $30^{\circ} \mathrm{C}$ in crimp-sealed tubes with an $\mathrm{N}_{2}$ atmosphere. Concentrations of perchlorate, chlorate, and acetate were measured using ion chromatography. Cells were quantified by optical density at $600 \mathrm{~nm}$ (OD600). Isolation of chlorate-reducing strains was performed by streaking twice onto oxic solid media and confirmed by Sanger sequencing of individual colonies' 16S rRNA genes.

\section{Quantification of perchlorate- and chlorate-reducing microorganisms}

Primers to measure the model perchlorate-reducing bacterium Azospira suillum PS and model chlorate-reducing bacterium Pseudomonas stutzeri PDA were designed to bind variable regions of their respective small ribosomal subunit gene (16S rRNA) sequence and amplify $\sim 150 \mathrm{bp}$ sequence. Primers to measure all chlorate-reducing bacteria were designed to bind the chlorate reductase gene $(\operatorname{clr} A)$. The clrA gene consists of two phylogenetic groups (here termed groups 1 and 2) with highest similarity to the alpha subunits of selenate reductase or dimethylsulfide dehydrogenase, respectively [34]. Specific primer selection involved identifying highly conserved sequence positions within each $c l r A$ group but not across closely related genes. Related genes were identified by searching the NCBI NR database with BLASTP [58]. Primer-BLAST used Primer Pair Specificity to check against select genomes in the NCBI nonredundant database (Supplementary Table 2). Template DNA was quantified using qPCR with three technical replicates; a standard curve of known concentration; and SYBR qPCR Master Mix (Thermo Fisher Scientific) on a StepOnePlus qPCR machine (Applied Biosciences). Measurements were performed on four biological replicates sampled at the time of inoculation and at the last timepoint preceding stationary phase. Quantification of total extracted DNA used the Quant-iT dsDNA Assay Kit (Thermo Fisher Scientific).

The relative abundance of isolated chlorate-reducing strains in the enriched communities was determined from previous 16S rRNA gene amplicon data under Sequence Reads Archive accession SRP049563 [47]. We obtained amplicon sequence variants (ASVs) to differentiate between closely related taxa by using DADA2 v.1.10 with default settings and without pooling [59, 60]. 16S rRNA gene sequences from representative DPRM and DCRM were compared with ASVs using BLASTN [58]. Each ASV was assigned the taxonomy of the sequence with the highest percent identity above a threshold of $95 \%$ (approximately genus-level similarity). Relative abundance was calculated from the number of reads composing each ASV and the total reads per sample.

\section{Genetics}

Genetic deletions and insertions in Pseudomonas stutzeri PDA were performed using protocols, strains, and plasmids from previous work [14]. All primers, plasmids, and strains are included in Supplementary Tables 1 and 3. Vectors were introduced into Pseudomonas stutzeri PDA via conjugation with Escherichia coli WM3064. These vectors had regions of homology allowing allelic exchange for a clean deletion, which were obtained by selection on kanamycin and counter-selection on sucrose.

\section{Modeling}

Modeling of perchlorate and chlorate reduction used the Equilibrium Chemistry Approximation [61], a modification of Michaelis-Menton kinetics that can account for competition between organisms for substrates and competition between substrates for an enzyme's active site. The reaction rate for perchlorate reduction to chlorate by perchloratereducing bacteria is provided by Eq. 1:

$$
\begin{aligned}
V_{P R B}^{\mathrm{ClO}_{4}}= & V_{\max }^{\mathrm{ClO}_{4}} \cdot\left[B_{P R B}\right] \\
& \cdot \frac{\left[C l O_{4}\right]}{K_{M}^{C l O_{4}} \cdot\left(1+\frac{\left[C l O_{4}\right]}{K_{P R B, O}^{C l O_{4}}}+\frac{\left[C l O_{3}\right]}{K_{P R B, M}^{C l O_{3}}}+\frac{\left[B_{P R B}\right]}{K_{P R B, M}^{C l O_{4}}}\right)} \\
& \cdot \frac{[D O C]}{K_{P R B, M}^{D O C} \cdot\left(1+\frac{[D O C]}{K_{P R B, M}^{D O C}}+\frac{\left[B_{P R B}\right]}{K_{P R B, M}^{D O C}}+\frac{\left[B_{C R B}\right]}{K_{C R B, M}^{D O C}}\right)}
\end{aligned}
$$

where $V$ (concentration time ${ }^{-1}$ ) is reaction rate and $V_{\max }$ $\left(\right.$ time $\left.^{-1}\right)$ is the maximum growth rate; $\mathrm{B},\left[\mathrm{ClO}_{4}{ }^{-}\right],\left[\mathrm{ClO}_{3}{ }^{-}\right]$, and $[\mathrm{DOC}]$ (concentration) are, respectively, the density of cells and the concentration of perchlorate, chlorate, and dissolved organic carbon (acetate). $K_{\mathrm{m}}$ (concentration) is the 
half-saturation concentration for each substrate. Together, these terms define how maximum reaction rate is limited by the concentration of perchlorate and acetate, as well as the competition of Pcr for chlorate and perchlorate.

The reaction rate for chlorate reduction was described similarly for perchlorate-reducing bacteria (Eq. 2) and chlorate-reducing bacteria (Eq. 3). To simplify modeling, we present chlorate reduction as one step instead of three steps (involving the intermediates chlorite and oxygen). We included the assumption that chlorate-reducing bacteria are unaffected by perchlorate.

$$
\begin{aligned}
V_{P R B}^{C l O_{3}}= & V_{P R B, \max }^{C l O_{3}} \cdot\left[B_{P R B}\right] \\
& \cdot \frac{\left[C l O_{3}\right]}{K_{P R B, M}^{C l O_{3}} \cdot\left(1+\frac{\left[\mathrm{ClO}_{4}\right]}{K_{P R B, M}^{C l O}}+\frac{\left[C l O_{3}\right]}{K_{P R B, M}^{C l O_{3}}}+\frac{\left[B_{P R B}\right]}{K_{P R B, M}^{C l O_{3}}}+\frac{\left[B_{C R B}\right]}{K_{C R B, M}^{C l O}}\right)} \\
& \cdot \frac{[D O C]}{K_{P R B, M}^{D O C} \cdot\left(1+\frac{[D O C]}{K_{P R B, M}^{D O C}}+\frac{\left[B_{P R B}\right]}{K_{P R B, M}^{D O C}}+\frac{\left[B_{C R B}\right]}{K_{C R B, M}^{D O C}}\right)}
\end{aligned}
$$

$$
\begin{aligned}
V_{C R B}^{C l O_{3}}= & V_{C R B, \max }^{C l O_{3}} \cdot\left[B_{C R B}\right] \\
& \cdot \frac{\left[C l O_{3}\right]}{K_{C R B, M}^{C l O_{3}} \cdot\left(1+\frac{\left[C l O_{3}\right]}{K_{C R B, M}^{C l O}}+\frac{\left[B_{P R B}\right]}{K_{P R B, M}^{C l O}}+\frac{\left[B_{C R B}\right]}{K_{C R B, M}^{C O}}\right)} \\
& \cdot \frac{[D O C]}{K_{C R B, M}^{D O C} \cdot\left(1+\frac{[D O C]}{K_{C R B, M}^{D O C}}+\frac{\left[B_{P R B}\right]}{K_{P R B, M}^{D O C}}+\frac{\left[B_{C R B}\right]}{K_{C R B, M}^{D O C}}\right)}
\end{aligned}
$$

The biomass yield and stoichiometry were calculated using the framework provided by Rittmann and McCarty [62]. Calculations required redox potentials and balanced halfreactions for the reduction of perchlorate to chlorate, the reduction of chlorate to chloride (via an oxygen intermediate), and the oxidation of acetate to carbon dioxide. Detailed methods and Python code are available at https://github.com/ tylerbarnum/perchlorate-and-chlorate-reduction-2019. Unless otherwise noted, simulations of the model involved a theoretical case with all values equal for perchlorate-reducing bacteria and chlorate-reducing bacteria except for the ability to use perchlorate as a substrate (Table 1).

\section{Results}

\section{Infiltration of perchlorate-reducing cultures by chlorate-reducing bacteria}

Genomic sequencing of perchlorate-reducing cultures revealed large populations of chlorate-reducing bacteria, hinting to a metabolic interaction between perchlorate and chlorate reduction. The cultures had been obtained
Table 1 Parameters for growth kinetics model. Populations were identical except for enzyme affinity for perchlorate, which for population 2 was set to be negligible $\left({ }^{\mathrm{a}}\right)$.

\begin{tabular}{lll}
\hline Parameter & Population 1 & Population 2 \\
\hline $\mathrm{Km} \mathrm{ClO}_{4}^{-}(\mathrm{mM})$ & 0.006 & $10,000^{\mathrm{a}}$ \\
$\mathrm{Km} \mathrm{ClO}_{3}^{-}(\mathrm{mM})$ & 0.007 & 0.007 \\
$\mathrm{Km} \mathrm{C}_{2} \mathrm{H}_{3} \mathrm{O}_{2}^{-}(\mathrm{mM})$ & 1 & 1 \\
Max. growth rate $\left(\mathrm{h}^{-1}\right)$ & 0.5 & 0.5 \\
Death rate $\left(\mathrm{h}^{-1}\right)$ & 0 & 0 \\
Type & Perchlorate reducer & Chlorate reducer
\end{tabular}

${ }^{\mathrm{a}}$ Set to be negligible.

previously by selecting colonies from perchlorate-reducing enrichments and confirming their isolation with Sanger sequencing of the $16 \mathrm{~S}$ ribosomal RNA gene [47]. Despite appearing axenic, the nine cultures produced a total of 16 genomes after assembly and binning: four draft genomes from axenic cultures, and 11 high-quality draft MAGs and one medium-quality draft MAG from mixed cultures (Fig. 1b) (Supplementary Table 4). Every less-abundant MAG was either at low relative abundance (0.9-9.5\%) or in the same taxonomic family as the most-abundant MAG, which likely caused the failure to detect contaminating strains through 16S rRNA gene sequencing. Annotation of MAGs and assembly graphs identified genes for perchlorate reduction ( $p c r, c l d$, and a terminal oxidase) in only nine genomes. Unexpectedly, while perchlorate and acetate, a non-fermentable carbon source, were the only energy substrates available in the growth medium, MAGs lacking $p c r$ were the most abundant organisms in several cultures (Fig. 1b). Instead, these three MAGs contained a complete chlorate reduction pathway ( $c l r, c l d$, and a terminal oxidase) (Supplementary Fig. 1).

The putative chlorate-reducing bacteria accounted for 69-90\% of cells in the perchlorate-reducing cultures (Fig. 1b), which is similar to what we previously observed in a perchlorate-enriched community [15]. The dominance of putative chlorate-reducing bacteria could be visually confirmed by comparing the number of colonies that develop on anaerobic tubes containing chlorate or perchlorate as the sole terminal electron acceptor (Fig. 1c). Subsequent isolation and characterization of Marinobacter vinifirmus UCB, Azoarcus marinus PHD, and Pseudomonas stutzeri CAL confirmed the strains to be strictly chlorate-respiring microorganisms, as no perchlorate was consumed after two weeks of incubation (data not shown) or co-metabolized during dissimilatory chlorate reduction by any strain (Fig. 1d). Because these strains cannot consume perchlorate themselves, the most parsimonious explanation of the observed community structure is that a perchlorate-reducing population supported a larger chloratereducing population. 
A. Defined co-cultures

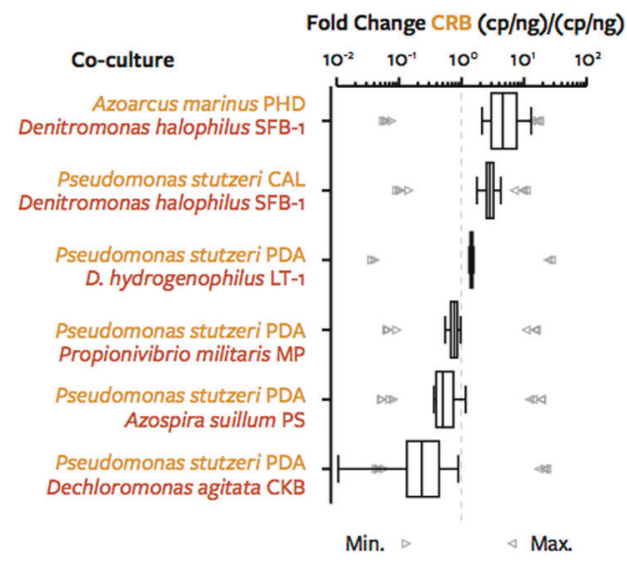

B. Communities

Community Replicate (\#)

Sediment

\begin{tabular}{|l}
$1 \% \mathrm{NaCl}$ \\
$(14 \mathrm{~d})$ \\
$3 \% \mathrm{NaCl}$ \\
$(28 \mathrm{~d})$ \\
\\
$5 \% \mathrm{NaCl}$ \\
$(42 \mathrm{~d})$ \\
$7 \% \mathrm{NaCl}$ \\
$(42 \mathrm{~d})$
\end{tabular}

Fig. 2 Co-cultivation of perchlorate-reducing bacteria (red, PRB) and chlorate-reducing bacteria (orange, CRB) in defined and undefined communities. a Fold change of $\operatorname{clr} A$ in defined co-cultures between lag phase and late exponential phase batch growth. For the co-culture consisting of $P$. stutzeri PDA and A. suillum PS, primers for $16 \mathrm{~S}$ rRNA genes were used. Arrows indicate the upper and lower bounds of fold change estimated from the initial and final OD600 of

\section{Perchlorate reduction supports chlorate-reducing bacteria in simple and complex communities}

The interaction between perchlorate- and chlorate-reducing bacteria was validated using defined co-cultures. Perchlorate- and chlorate-reducing strains were inoculated at equal cell densities (OD600) into anoxic media with perchlorate as the sole electron acceptor, and the relative number of chlorate-reducing cells between inoculation and the start of stationary phase was measured using the copy number of chlorate reductase alpha subunit (clrA) determined by qPCR. Chlorate-reducing strains grew in every co-culture with perchlorate-reducing bacteria (Fig. 2a). No growth was observed in control media that lacked an electron acceptor (Supplementary Fig. 2). The fitness of the chlorate-reducing bacteria was dependent on the partner perchlorate-reducing bacterium, with Denitromonas halophilus SFB-1 supporting the most growth of chloratereducing bacteria and Dechloromonas agitata CKB supporting the least growth (Fig. 2a). Thus, all tested perchlorate-reducing strains supported some growth of chlorate-reducing bacteria.

To determine if this interaction occurs in more complex communities, we quantified the abundance of isolated strains in the original perchlorate-reducing enrichments using previously published $16 \mathrm{~S}$ rRNA gene amplicon data [47]. Indeed, ASVs corresponding to isolated chloratereducing strains in the genera Azoarcus and Pseudomonas, which are not known to contain perchlorate-reducing species, were highly abundant $(>20 \%)$ in six of ten

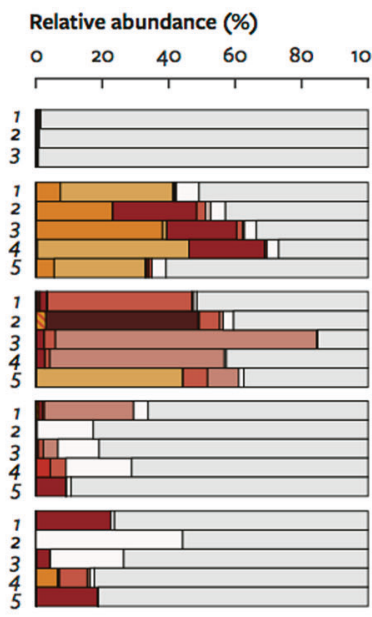

Highest similarity to ASV

$\square$ Pseudomonas stutzeri PDA

뜬 $\square$ Azoarcus marinus BM101

Q Marinobacter vinifirmus $\mathrm{P}_{4} \mathrm{~B}_{1}$ *

- Denitromonas halophilus SFB-1

- Arcobacter sp. BM102

m $\square$ Arcobacter sp. BM504

ㄴ. $\square$ Sedimenticola selenatireducens BK-1

$\square$ Sedimenticola thiotaurini UCB-2

$\square$ Sulfurospirillum cavolei Phe91 *

$\square$ Sulfurimonas denitrificans DSM 1251 *

$\square$ Taxa without PRB or CRB

the co-culture. Boxplots indicate quartiles in the sample. b Relative abundance of $16 \mathrm{~S}$ rRNA gene amplicon sequence variants grouped by similarity to the $16 \mathrm{~S}$ rRNA genes of perchlorate- and chlorate-reducing taxa. Stacked bars are in the same order as the legend. *, strains most closely related to perchlorate-reducing MAGs for which 16S rRNA genes were not available.

communities at low salinity (Fig. 2b). In those communities, the ASVs affiliated with chlorate reduction accounted for $23-46 \%$ of total bacteria and archaea in the community and $40-84 \%$ of putative chlorate- and perchlorate-reducing taxa. Chlorate-reducing bacteria and perchlorate-reducing bacteria were found in various combinations in communities. That many different perchlorate-reducing bacteria can support the growth of chlorate-reducing bacteria, in both cocultures and communities, demonstrated that the interaction is based not on strain-specific traits but on conserved features of the metabolic pathways involved.

\section{Chlorate-reducing bacteria require the perchlorate reduction intermediate chlorate}

Chlorate-reducing bacteria are able to use all components of the perchlorate reduction pathway except perchlorate (Fig. 1a), so we sought to determine which intermediates were responsible for the metabolic interaction. We deleted different steps of the chlorate reduction pathway in the model chlorate-reducing bacterium Pseudomonas stutzeri PDA (PDA). Measuring the fitness of each of these mutants in co-culture with the model perchlorate-reducing bacterium Azospira suillum PS (PS) would demonstrate which steps of the chlorate reduction pathway were essential for growth from perchlorate reduction intermediates. Genes encoding enzymes for reactions upstream of an exchanged intermediate are non-essential for growth, whereas genes encoding enzymes for reactions downstream of the exchanged intermediate are essential. For example, if 
A. P. stuterzi PDA Pathway Phenotype

$$
\begin{array}{lll}
\text { wt } & \mathrm{ClO}_{3} \stackrel{\mathrm{Clr}}{\longrightarrow} \mathrm{ClO}_{2} \stackrel{\mathrm{Cld}}{\longrightarrow} \mathrm{O}_{2} \stackrel{\mathrm{TO}}{\longrightarrow} \mathrm{H}_{2} \mathrm{O} \\
\text { sclr } & & \mathrm{ClO}_{2}^{-} \stackrel{\mathrm{Cld}}{\longrightarrow} \mathrm{O}_{2} \stackrel{\mathrm{TO}}{\longrightarrow} \mathrm{H}_{2} \mathrm{O} \\
\Delta \text { clr } \Delta \text { cld } & & \mathrm{O}_{2} \stackrel{\mathrm{TO}}{\longrightarrow} \mathrm{H}_{2} \mathrm{O} \\
\Delta \text { cld } & \mathrm{ClO}_{3} \stackrel{\mathrm{Clr}}{\longrightarrow} \mathrm{ClO}_{2}^{-} & \mathrm{O}_{2} \stackrel{\mathrm{TO}}{\longrightarrow} \mathrm{H}_{2} \mathrm{O}
\end{array}
$$

B. Fitness in Co-culture with A. suillum PS

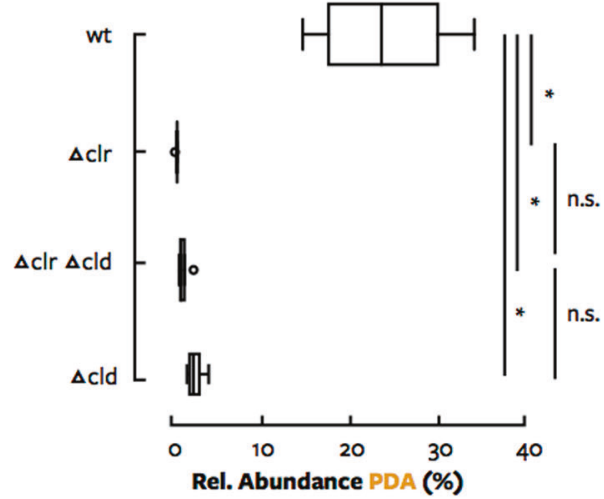

c.

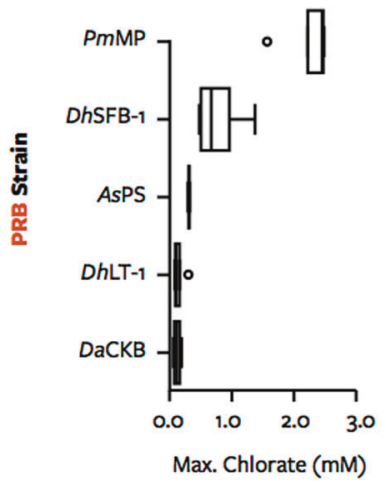

D.

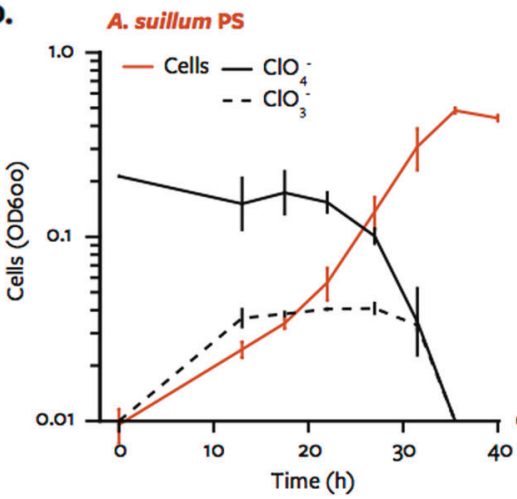

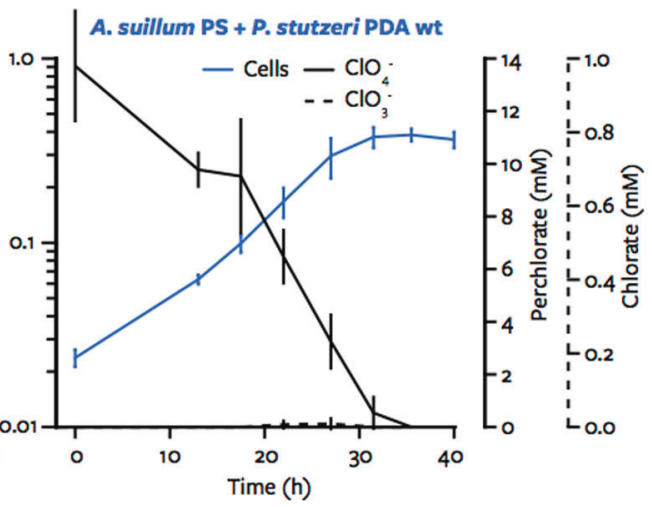

Fig. 3 Determination of the perchlorate reduction intermediate that supports growth chlorate-reducing bacteria in defined cocultures. a Genotype and phenotype (in pure culture) of chlorate reduction pathway mutants constructed in Pseudomonas stutzeri PDA (PDA). A chlorate reduction mutant would be unable to grow unless it can use the intermediate produced by perchlorate-reducing bacteria as a respiratory electron acceptor. b Fitness of chlorate reduction mutants in co-culture with Azospira suillum PS (PS) provided $10 \mathrm{mM}$ perchlorate and $40 \mathrm{mM}$ lactate, which PDA does not ferment. Relative

chlorite were the exchanged intermediate, PS growing by perchlorate reduction would support growth of PDA strains lacking $\operatorname{clr} A$ but not PDA strains lacking $c l d$ (Fig. 3a).

In the co-cultures inoculated with equal cell densities of PS and PDA, growth of wild type PDA was characterized by a final relative abundance of $27 \%$ (final ratio PDA/PS = 0.37) (Fig. 3b). In contrast, deletion of any steps of the chlorate reduction pathway prevented growth of PDA: the final abundance of PDA deletion strains $\left(\mathrm{PDA}_{\mathrm{del}} / \mathrm{PS}<\right.$ 0.048) was equivalent to that expected with no growth of PDA (PDA/PS <0.060) (Fig. 3a). While all chlorate reduction genes were necessary, the particular necessity of chlorate reductase $(\operatorname{clr} A)$ demonstrated that chlorate is the only intermediate exchanged in enough quantity to support measurable growth. That is, chlorite dismutase and terminal oxidases are present in the PDA $c l r A$ deletion strain, yet any release of chlorite or oxygen by PS during perchlorate reduction was not sufficient to support growth of PDA. abundance was calculated from qPCR measurements of both the PS and PDA 16S rRNA genes. *, significance of $p<0.05$ (two-sided $T$ test); n.s., $p>0.05$. Boxplots indicate quartiles in the sample with outliers as circles. c Maximum concentration of chlorate during dissimilatory perchlorate reduction by different strains of perchloratereducing bacteria (PRB) supplied $10 \mathrm{mM}$ perchlorate. d Concentrations of perchlorate and chlorate during dissimilatory perchlorate reduction by PS or PS and PDA. Errors bars represent standard deviation of at least three replicates.

Thus, the basis of the metabolic interaction is the transfer of chlorate from perchlorate-reducing cells to chloratereducing cells.

Other observations supported chlorate as the exchanged intermediate. Perchlorate-reducing bacteria accumulated chlorate at concentrations between 1 and $22 \% \mathrm{~mol} / \mathrm{mol}$ of initial perchlorate $(\sim 10 \mathrm{mM})$ (Fig. 3c), as reported previously [45, 63]. In addition, chlorate accumulated in pure cultures of PS $(<0.3 \mathrm{mM})$ but was consumed in co-cultures of PS and wild type PDA (Fig. 3d). However, there was no clear relationship between the maximum concentration of chlorate that accumulated in pure cultures of perchloratereducing bacteria (Fig. 3c) and the fitness of chloratereducing bacteria in co-culture (Fig. 2a). Notably, kinetics differed between PS cultures with and without wild type PDA (Fig. 3d, Supplementary Fig. 3). When PDA was present, the maximum growth rate and maximum perchlorate reduction rate by PS decreased and the onset of 
A.

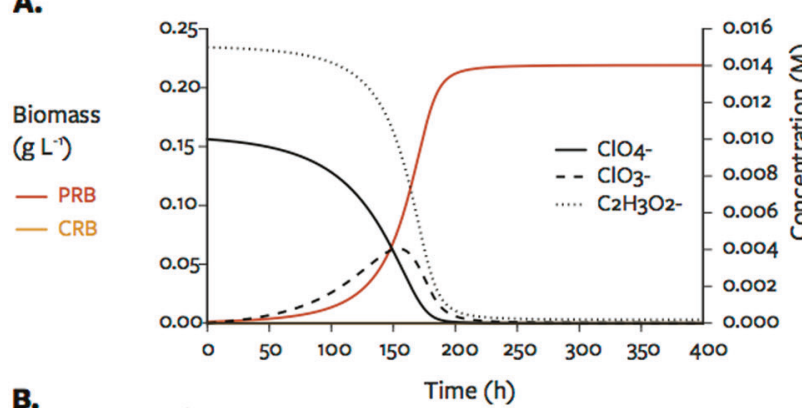

B.

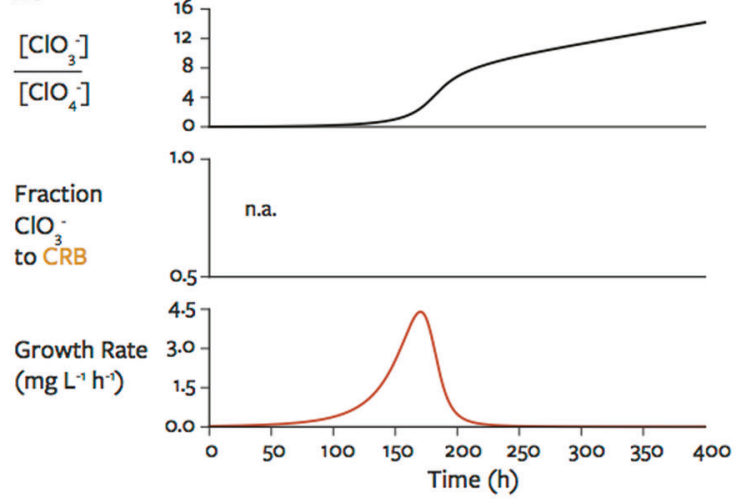

c.

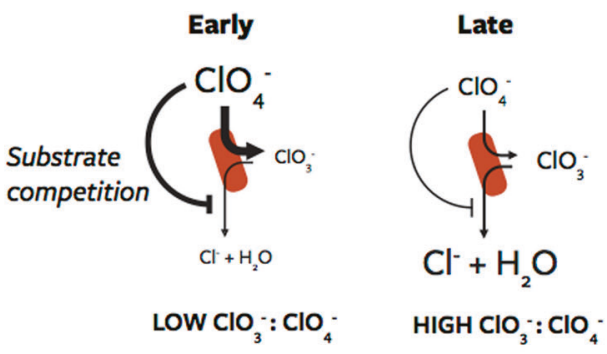

Fig. 4 Modeling of perchlorate reduction and chlorate reduction. Simulated growth curves for perchlorate-reducing bacteria $(\mathbf{a}-\mathbf{c})$ alone and $(\mathbf{d}-\mathbf{f})$ with chlorate-reducing bacteria. $\left[\mathrm{ClO}_{3}{ }^{-}\right] /\left[\mathrm{ClO}_{4}{ }^{-}\right]$, the ratio between chlorate concentration and perchlorate concentration; fraction

growth and perchlorate reduction was earlier when compared to the pure PS culture (Fig. 3d). Similar changes in growth kinetics were observed in other co-cultures (Supplementary Fig. 2). The kinetics of chlorate production and consumption thus seemed to be an important factor in the interaction.

\section{Specificity for chlorate enables chlorate-reducing cells to exploit perchlorate-reducing cells}

An understanding of the kinetics of the interaction was necessary to understand how chlorate release could produce the observed community structure. For example, how can accumulation of chlorate to only $3 \%$ of initial perchlorate concentration support chlorate-reducing bacteria at $27 \%$ of the community (Fig. 3)? More generally, how can a population with the partial pathway outcompete a population with the complete pathway up to a factor of nearly ten (Figs. 1 and
D.

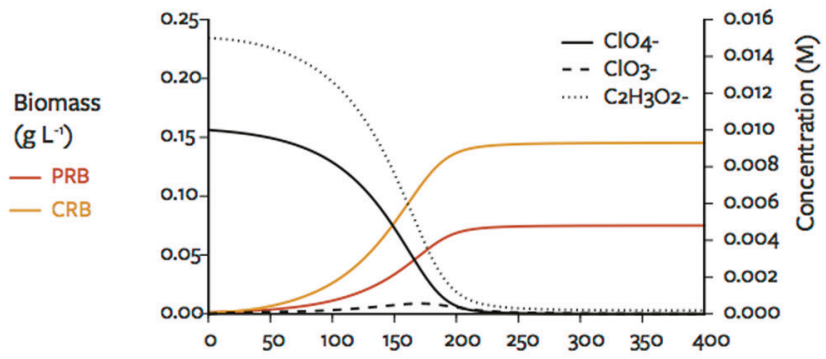

E.

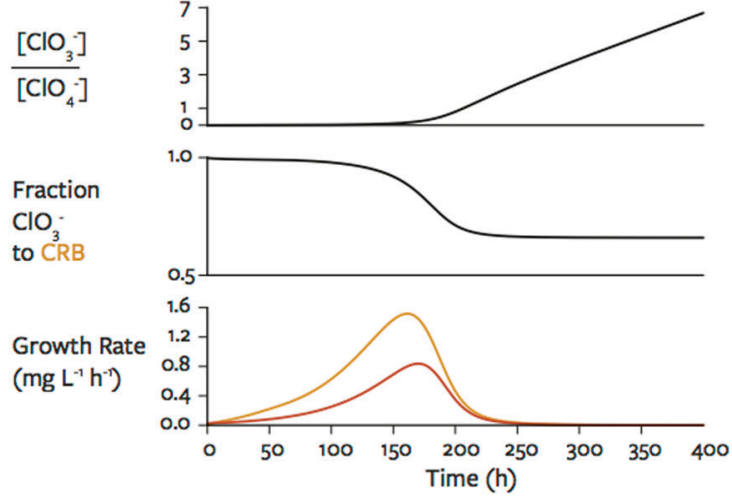

F.

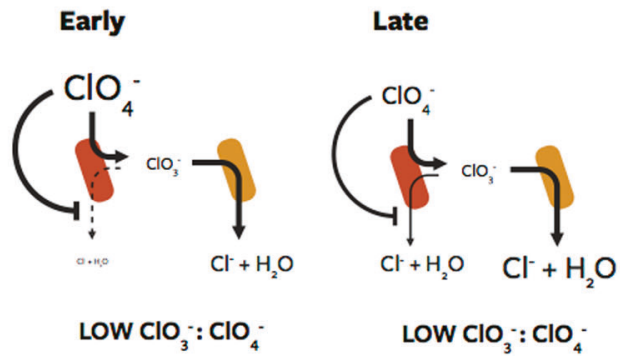

$\mathrm{ClO}_{3}{ }^{-}$to $\mathrm{CRB}$ indicates the relative amount of chlorate consumed by the chlorate-reducing population at each time step; growth rate, the change in cell concentration between each time step.

2)? To answer these questions, we used simulations of an Equilibrium Chemistry Approximation kinetics model, which included the effects of substrate competition within and between cells. We focused on the theoretical case where (1) the kinetics of chlorite and oxygen are ignored and (2) chlorate- and perchlorate-reducing populations were identical (maximum growth rate, yield, etc.) except for substrate utilization (Table 1, Eqs. 1-3): populations could use both perchlorate and chlorate or only chlorate. Therefore, the model's salient features were the yields and rates from the production and consumption of chlorate, as well as the competition of perchlorate and chlorate for Pcr. In simulations with the perchlorate-reducing population alone, these parameters led to the accumulation of chlorate during perchlorate reduction (Fig. 4a). Importantly, growth rate was lower while the $\mathrm{ClO}_{3}{ }^{-}: \mathrm{ClO}_{4}{ }^{-}$ratio was low (Fig. 4b). Chlorate influenced growth rate so strongly because chlorate reduction to chloride provided more energy $(622.9 \mathrm{~kJ} / \mathrm{mol}$ 
chlorate) than perchlorate reduction to chlorate $(211.7 \mathrm{~kJ} / \mathrm{mol}$ perchlorate). At low $\mathrm{ClO}_{3}{ }^{-}: \mathrm{ClO}_{4}{ }^{-}$ratios, the perchloratereducing population was less likely to reduce chlorate and more likely to reduce perchlorate because the concentration of $\mathrm{ClO}_{4}^{-}$was much higher (Fig. 4c).

Accordingly, we hypothesized that a population that could only reduce chlorate would have a higher growth rate at low $\mathrm{ClO}_{3}{ }^{-}: \mathrm{ClO}_{4}{ }^{-}$ratios than the perchlorate-reducing population. We tested this by adding the chlorate-reducing population to the simulation at equal initial concentration. The chlorate-reducing population outcompeted the perchlorate-reducing population and decreased the concentration of chlorate (Fig. 4d), consistent with experimental observations. In support of our hypothesis, at low $\mathrm{ClO}_{3}{ }^{-}: \mathrm{ClO}_{4}{ }^{-}$ratios the chlorate-reducing population consumed almost all of the chlorate and had a higher growth rate (about twofold) than the perchlorate-reducing population (Fig. 4e). With chlorate-reducing cells present, the consumption of chlorate delayed the increase of the $\mathrm{ClO}_{3}{ }^{-}$: $\mathrm{ClO}_{4}{ }^{-}$ratio (Fig. 4b, e). Thus, in this simple theoretical case, chlorate-reducing cells had a growth advantage because they, unlike perchlorate-reducing cells, could consume chlorate at high perchlorate concentrations (Fig. 4f). Additionally, the consumption of chlorate by chloratereducing bacteria created a positive feedback by maintaining a low $\mathrm{ClO}_{3}{ }^{-}: \mathrm{ClO}_{4}{ }^{-}$ratio (Fig. 4c, f).

We used additional simulations to observe how initial conditions affect the interaction. Varying the initial ratio of chlorate-reducing cells to perchlorate-reducing cells did not alter the ecological success or the fraction of chlorate acquired by the chlorate-reducing population (Supplementary Fig. 4A, B); Chlorate-reducing cells ultimately dominated by acquiring a large percent of chlorate unless initially outnumbered 100-fold (Supplementary Fig. 4c). Varying perchlorate concentration, however, did alter the success of chlorate-reducing cells (Supplementary Fig. 4D-F). Even when chlorate-reducing cells outnumbered perchloratereducing cells, the perchlorate-reducers consumed nearly all available chlorate except at perchlorate concentrations above $\sim 1 \mathrm{mM}$ (Supplementary Fig. 4E). Also, varying the affinity of different populations for perchlorate or chlorate altered the ecological success of chlorate-reducing cells (Supplementary Fig. 5). While not necessarily predictive of behavior in the environment or over different temporal and spatial scales, these simulations provide an intuitive description of the interaction: chlorate-reducing cells exploit a niche made available by differences in enzyme kinetics and substrates.

\section{Discussion}

This study confirms and further interrogates the interaction between perchlorate reduction and chlorate reduction. Here we clearly demonstrate that bacteria with the perchlorate reduction pathway supported-and could be outcompeted by-bacteria with the chlorate reduction pathway, thus creating a parasitic symbiosis. The interaction between perchlorate and chlorate reduction occurred in both controlled (i.e., co-cultures) and uncontrolled systems (i.e., enrichment and isolation) and in both freshwater and marine conditions. The basis of the interaction was the exchange of transiently produced chlorate from perchlorate-reducing cells to chlorate-reducing cells. Chlorate was available for consumption likely due to competition of perchlorate and chlorate for a single enzyme in the periplasm of perchloratereducing cells [41]. Simulations showed that the chloratereducing cells are successful because chlorate can be reduced even at a low $\mathrm{ClO}_{3}{ }^{-}: \mathrm{ClO}_{4}{ }^{-}$ratio, a state that chlorate consumption perpetuates. In summary, chloratereducing bacteria were a common feature of perchlorate reduction and had a large effect on the structure and function of perchlorate-reducing communities.

The basis of the parasitic interaction alters our understanding of the chlorine cycle. Perchlorate reduction involves the combined activity of perchlorate-reducing microorganisms, chlorate-reducing microorganisms, and any chemical reduction of their intermediates (Fig. 5). A role for chlorite-consuming or oxygen-consuming partial pathways in perchlorate reduction was not observed here (Fig. 3), and an interaction based on the exchange of chlorite has been engineered [14] but not yet observed in nature. This is likely due to the high activity $\left(k_{\mathrm{ca}} / K_{\mathrm{M}}\right)$ of chlorite dismutase $\left(10^{6}-10^{8} \mathrm{M}^{-1} \mathrm{~s}^{-1}\right)$ relative to perchlorate reductase $\left(\sim 10^{5} \mathrm{M}^{-1} \mathrm{~s}^{-1}\right)$ [46, 64]. Because chlorate is less reactive than chlorite, cells that inadvertently reduce chlorate to chlorite would experience greater reactive chlorine stress; chlorite dismutase (Cld) can detoxify chlorite produced in this manner [65]. In addition, the exchange of chlorate is less constrained by the reducing state of the environment than the exchange of chlorite. But chlorate does react with common environmental reductants such as reduced iron minerals [66, 67], and the reactivity of chlorate with iron increases with salinity [67], which may contribute to the lower frequency of chlorate-reducing bacteria in higher-salinity perchlorate-reducing enrichments (Fig. 2b). The concentrations of reductants, chlorate, and perchlorate may all influence the relative contribution of perchlorate-reducing microorganisms and chlorate-reducing microorganisms to chlorine oxyanion respiration.

Interactions like that described here, where low accumulation of an intermediate supports large populations with a partial respiratory pathway, may be common across elemental cycles. Some evidence exists for the importance of these interactions in denitrification, for example. Pseudomonas strain G9, which contains a complete denitrification pathway producing inhibitory concentrations of nitrite, 


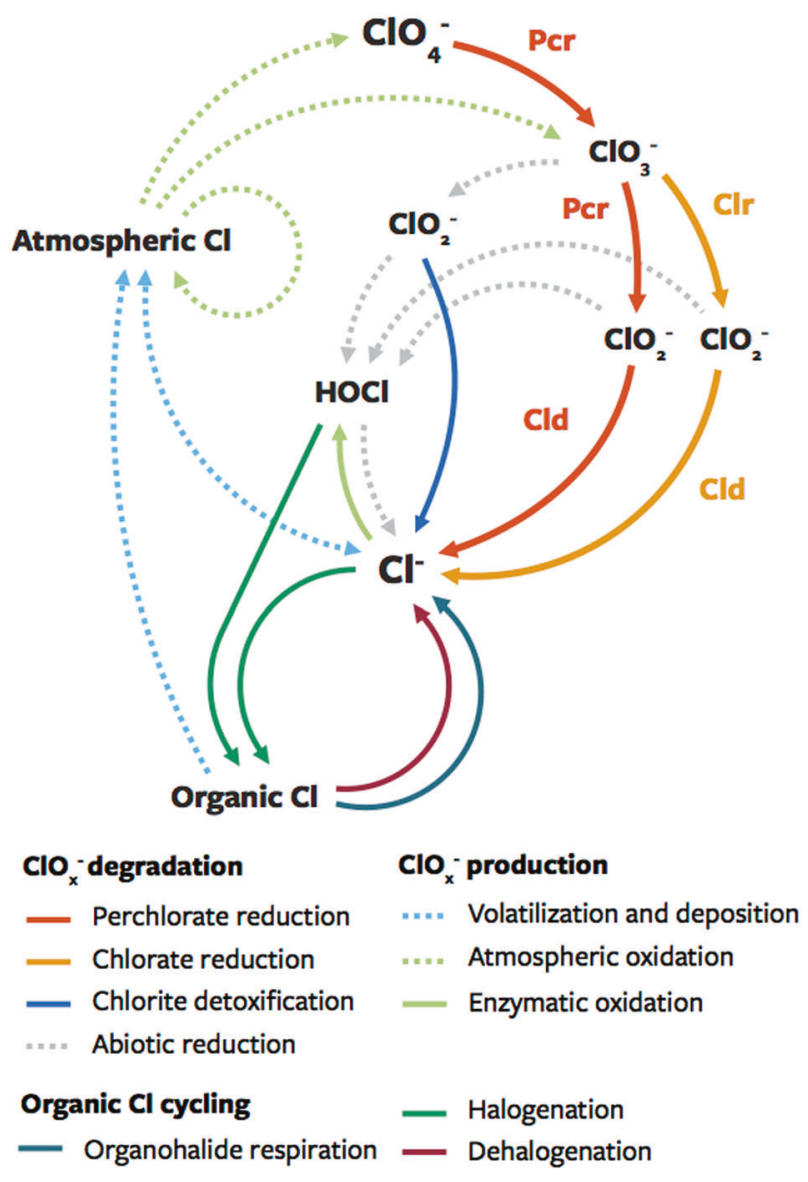

Fig. 5 Model for the production and degradation of chlorine oxyanions. The perchlorate reduction pathway (red) accumulates chlorate, which can react with reductants and generate reactive chlorine species (gray) or be consumed by the chlorate reduction pathway (orange). We did not find evidence for the release of chlorite and oxygen by the perchlorate and chlorate reduction pathways, though both chemicals can react with any reductants in the periplasm. Perchlorate and chlorate reduction remove the products of atmospheric oxidation of chlorine (dashed yellow). Co-metabolic or inadvertent enzyme activities are not shown.

could grow only in co-culture with Alcaligenes faecalis strain TUD, which only reduces nitrite to dinitrogen, and the two strains were found at steady state at approximately equal cell densities [16]. Nitrite accumulation caused by inter-enzyme competition in Pseudomonas stutzeri strain A1501 was decreased by dividing nitrite production and consumption between different strains [26]. In denitrifying communities, then, it may be beneficial for some organisms to lack steps in the denitrification pathway. This was the case for a pooled transposon mutant library of Azospira suillum PS, where mutants with insertions in nitrite reductase, which is deleterious in pure culture, outcompeted cells with intact denitrification pathways [8]. Much remains to be learned about community structure impacts resulting from pathway distribution across different populations.
The importance of studying metabolic interactions in biogeochemical transformations is to learn how such interactions influence concentrations and rates. Previous studies that added chlorate-reducing bacteria to cultures of the perchlorate-reducing bacterium HCAP-C, which accumulates far more chlorate than the typically observed [44-46], had conflicting results where chlorate-reducing bacteria either slightly accelerated [42] or substantially decelerated the rate of perchlorate reduction [40]. We observed that adding chlorate-reducing bacteria to cultures of the model perchlorate-reducing bacterium Azospira suillum PS decreased each of: (i) the concentration of chlorate; (ii) the maximum growth rate; and (iii) the maximum perchlorate reduction rate (Fig. 3d), thus identifying it as a parasitic interaction. Similar effects on growth rate were observed with perchlorate-reducing bacteria that accumulated varying concentrations of chlorate (Supplementary Fig. 2, Fig. 3c), and we directly demonstrated success of chlorate-reducing populations at the expense of perchlorate-reducing populations (Fig. 2), though the success of chlorate-reducing populations differed between cultures for unknown reasons. Because chlorate reduction appears to substantially influence concentrations and rates during perchlorate reduction, chlorate-reducing bacteria could affect efforts to bioremediate perchlorate. For example, a description of perchlorate-reducing bioreactors with gene-centric metagenomics identified Azoarcus and Pseudomonas as among the most abundant genera, yet the Azoarcus isolate did not reduce perchlorate [68]. Our results predict that those organisms are chlorate-reducing bacteria that persisted in the bioreactors for over 10 years [68]. Understanding how this metabolic interaction affects perchlorate reduction kinetics in different communities and systems, and how it could be controlled, may be a promising line of future research.

A close interaction between metabolisms also has evolutionary implications, as co-occurrence can influence gene evolution and exchange. For example, in nitrifying microorganisms, niche differentiation led to high affinity and low affinity ammonia-oxidizing enzymes that function best at different $\mathrm{pH}$ [69] and to the exchange of ammonia monooxygenase to nitrite-oxidizing bacteria [70]. Not enough chlorate reductases and perchlorate reductases have been evaluated to draw general conclusions from their substrate affinities and catalytic rates. However, several chloratereducing bacteria contain genes or gene fragments of perchlorate reductase components (napC and $p c r D$ ) adjacent to the chlorite dismutase $(\mathrm{cld})$, and these genes were most likely acquired from perchlorate-reducing bacteria [34]. Because environmental reduction of perchlorate or chlorate will likely involve both perchlorate-reducing microorganisms and chlorate-reducing microorganisms, a history of gene exchange between the two metabolisms is unsurprising. 


\section{Conclusions}

Perchlorate reduction supports chlorate reduction through the release of the intermediate chlorate. The fundamental cause of the interaction is that the perchlorate reductase enzyme catalyzes both perchlorate reduction to chlorate and chlorate reduction to chlorite-therefore chlorate competes with perchlorate for perchlorate reductase, limiting subsequent steps of the perchlorate reduction pathway. Chlorate reduction, despite being a partial pathway, is ecologically successful because it can consume chlorate unabated and, in doing so, exacerbates the imbalance between perchlorate and chlorate. As for several other respiratory metabolisms, the respiration of chlorine oxyanions in the environment should be expected to involve cells performing complete and partial respiratory pathways. These findings have clear implications for understanding the evolution and the kinetics of chlorine oxyanion reduction.

Acknowledgements Financial support was provided through a grant from the Energy Biosciences Institute EBI-BP program to JDC and through the NSF Graduate Research Fellowship Program to TPB. We thank Kelly Whetmore and the Adam Arkin Laboratory for performing library preparation and sequencing.

Author Contributions JDC guided the research. LNL and TPB isolated strains. LNL extracted DNA for sequencing. TPB assembled and analyzed genomes, designed primers, and performed amplicon sequence variant analysis. TPB and KAH performed all experiments and measurements. YC developed the model. YC and TPB performed and interpreted modeling simulations. With guidance from JDC, TPB wrote the manuscript and created the figures. All authors contributed to data analysis, reviewed the manuscript, and approved of its publication.

\section{Compliance with ethical standards}

Conflict of interest The authors declare that they have no conflict of interest.

Publisher's note Springer Nature remains neutral with regard to jurisdictional claims in published maps and institutional affiliations.

\section{References}

1. Atashgahi S, Liebensteiner MG, Janssen DB, Smidt H, Stams AJM, Sipkema D. Microbial synthesis and transformation of inorganic and organic chlorine compounds. Front Microbiol. 2018;9:1-22.

2. Liebensteiner MG, Oosterkamp MJ, Stams AJM. Microbial respiration with chlorine oxyanions: diversity and physiological and biochemical properties of chlorate- and perchlorate-reducing microorganisms. Ann NY Acad Sci. 2016;1365:59-72.

3. Palmisano A, Hazen T. Bioremediation of metals and radionuclides: what it is and how it works, 2 edn. United States: N. 2003. p. 2003.

4. Winterbourn CC. Reconciling the chemistry and biology of reactive oxygen species. Nat Chem Biol. 2008;4:278-86.
5. Youngblut MD, Wang O, Barnum TP, Coates JD. (Per)chlorate in biology on earth and beyond. Annu Rev Microbiol. 2016;70:435-459.

6. Gray MJ, Wholey W-Y, Jakob U. Bacterial responses to reactive chlorine species. Annu Rev Microbiol. 2013;67:141-60.

7. Hofbauer S, Howes BD, Flego N, Pirker KF, Schaffner I, Mlynek G, et al. From chlorite dismutase towards HemQ- the role of the proximal $\mathrm{H}$-bonding network in haeme binding. Biosci Rep. 2016;36:e00312.

8. Melnyk Ra, Youngblut MD, Clark IC, Carlson HK, Wetmore $\mathrm{KM}$, Price $\mathrm{MN}$, et al. Novel mechanism for scavenging of hypochlorite involving a periplasmic methionine-rich peptide and methionine sulfoxide reductase. mBio. 2015;6:e00233-00215.

9. Coates JD, Achenbach LA. Microbial perchlorate reduction: rocket-fueled metabolism. Nat Rev Microbiol. 2004;2:569-80.

10. Kounaves SP, Stroble ST, Anderson RM, Moore Q, Catling DC, Douglas S, et al. Discovery of natural perchlorate in the Antarctic Dry Valleys and its global implications. Environ Sci Technol. 2010;44:2360-4.

11. Melnyk RA, Coates JD. The perchlorate reduction genomic island: mechanisms and pathways of evolution by horizontal gene transfer. BMC Genomics. 2015;16:862.

12. Coates JD, Michaelidou U, Bruce RA, O'Connor SM, Crespi JN, Achenbach LA. Ubiquity and diversity of dissimilatory (per) chlorate-reducing bacteria. Appl Environ Microbiol. 1999;65:5234-41.

13. Rajagopalan S, Anderson T, Cox S, Harvey G, Cheng Q, Jackson WA. Perchlorate in wet deposition across North America. Environ Sci Technol. 2009;43:616-22.

14. Clark IC, Youngblut M, Jacobsen G, Wetmore KM, Deutschbauer A, Lucas L, et al. Genetic dissection of chlorate respiration in Pseudomonas stutzeri PDA reveals syntrophic (per)chlorate reduction. Environ Microbiol. 2016;18:3342-54.

15. Barnum TP, Figueroa IA, Carlström CI, Lucas LN, Engelbrektson AL, Coates JD. Genome-resolved metagenomics identifies genetic mobility, metabolic interactions, and unexpected diversity in perchlorate-reducing communities. ISME J. 2018;12:1568-81.

16. Van de Pas-Schoonen KT, Schalk-Otte S, Haaijer S, Schmid M, Op den Camp H, Strous M, et al. Complete conversion of nitrate into dinitrogen gas in co-cultures of denitrifying bacteria. Biochem Soc Trans. 2005;33:205-9.

17. Daims H, Lücker S, Wagner M. A new perspective on microbes formerly known as nitrite-oxidizing bacteria. Trends Microbiol. 2016;24:699-712.

18. Winogradsky S. Contributions a la morphologie des organismes de la nitrification. Arch Sci Biol. 1892;1:88-137.

19. Anantharaman K, Hausmann B, Jungbluth SP, Kantor RS, Lavy A, Warren LA, et al. Expanded diversity of microbial groups that shape the dissimilatory sulfur cycle. ISME J. 2018;12: $1715-28$.

20. Kelly DP, Shergill JK, Lu W-P, Wood AP. Oxidative metabolism of inorganic sulfur compounds by bacteria. Antonie Van Leeuwenhoek. 1997;71:95-107.

21. Grostern A, Edwards EA. Growth of Dehalobacter and Dehalococcoides spp. during degradation of chlorinated ethanes. Appl Environ Microbiol. 2006;72:428-36.

22. Anantharaman K, Brown CT, Hug LA, Sharon I, Castelle CJ, Probst AJ, et al. Thousands of microbial genomes shed light on interconnected biogeochemical processes in an aquifer system. Nat Commun. 2016;7:13219.

23. Costa E, Perez J, Kreft J-U. Why is metabolic labour divided in nitrification? Trends Microbiol. 2006;14:213-9.

24. Dolinšek J, Goldschmidt F, Johnson DR. Synthetic microbial ecology and the dynamic interplay between microbial genotypes. FEMS Microbiol Rev. 2016;40:961-79. 
25. Hallin S, Philippot L, Löf FE, Sanford RA, Jones CM. Genomics and ecology of novel $\mathrm{N}_{2} \mathrm{O}$-reducing microorganisms. Trends Microbiol. 2018;26:43-55.

26. Lilja EE, Johnson DR. Segregating metabolic processes into different microbial cells accelerates the consumption of inhibitory substrates. ISME J. 2016;10:1568-78.

27. Wolterink AFWM, Schiltz E, Hagedoorn P-1, Hagen WR. Characterization of the chlorate reductase from Pseudomonas chloritidismutans. J Bacteriol. 2003;185:3210-3.

28. Hofbauer S, Schaffner I, Furtmüller PG, Obinger C. Chlorite dismutases - a heme enzyme family for use in bioremediation and generation of molecular oxygen. Biotechnol J. 2014;9:461-73.

29. Bender KS, O'Connor SM, Chakraborty R, Coates JD, Achenbach LA. Sequencing and transcriptional analysis of the chlorite dismutase gene of Dechloromonas agitata and its use as a metabolic probe. Appl Environ Microbiol. 2002;68:4820-6.

30. Van Ginkel CG, Rikken GB, Kroon AGM, Kengen SWM. Purification and characterization of chlorite dismutase: A novel oxygen-generating enzyme. Arch Microbiol. 1996;166:321-6.

31. Clark IC, Melnyk Ra, Iavarone AT, Novichkov PS, Coates JD. Chlorate reduction in Shewanella algae ACDC is a recently acquired metabolism characterized by gene loss, suboptimal regulation, and oxidative stress. Mol Microbiol. 2014;94:107-25.

32. Sun Y. Physiology of microbial perchlorate reduction. $\mathrm{PhD}$ dissertation. Berkeley, CA, UC Berkeley 2008.

33. Rikken GB, Kroon AGM, Van Ginkel CG. Transformation of (per)chlorate into chloride by a newly isolated bacterium: reduction and dismutation. Appl Microbiol Biotechnol. 1996;45:420-6.

34. Clark IC, Melnyk Ra, Engelbrektson A, Coates JD. Structure and evolution of chlorate reduction composite transposons. mBio. 2013;4:e00379-00313.

35. Melnyk Ra, Engelbrektson A, Clark IC, Carlson HK, ByrneBailey K, Coates JD. Identification of a perchlorate reduction genomic island with novel regulatory and metabolic genes. Appl Environ Microbiol. 2011;77:7401-4.

36. Liebensteiner MG, Pinkse MWH, Schaap PJ, Stams AJM, Lomans BP. Archaeal (per)chlorate reduction at high temperature: an interplay of biotic and abiotic reactions. Science. 2013;340:85-87.

37. Liebensteiner MG, MWH Pinkse, Nijsse B, PDEM Verhaert, Tsesmetzis N, AJM Stams, et al. Perchlorate and chlorate reduction by the Crenarchaeon Aeropyrum pernix and two thermophilic Firmicutes. Environ Microbiol Rep. 2015;7:936-45.

38. Martínez-Espinosa RM, Richardson DJ, Bonete MJ. Characterisation of chlorate reduction in the haloarchaeon Haloferax mediterranei. Biochim Biophys Acta. 2015;1850:587-94.

39. Malmqvist Å, Welander T, Moore E, Ternström A, Molin G, Stenström I-MJS. et al. Ideonella dechloratans gen. nov., sp. nov., a new bacterium capable of growing anaerobically with chlorate as an electron acceptor. Syst Appl Microbiol. 1994;17:58-64.

40. Dudley M, Nerenberg R. Microbial ecology of perchloratereducing bacteria that accumulate high levels of chlorate. Master's thesis, University of Notre Dame; 2007.

41. Dudley M, Salamone A, Nerenberg R. Kinetics of a chlorateaccumulating, perchlorate-reducing bacterium. Water Res. 2008;42:2403-10.

42. Salamone AR, Nerenberg R. Kinetics of a perchlorate-reducing bacterium that accumulates high levels of chlorate. Master's thesis, University of Notre Dame; 2006.

43. Nerenberg R, Kawagoshi Y, Rittmann BE. Kinetics of a hydrogen-oxidizing, perchlorate-reducing bacterium. Water Res. 2006;40:3290-6.

44. Cameron Thrash J, Ahmadi S, Torok T, Coates JD. Magnetospirillum bellicus sp. nov., a novel dissimilatory perchloratereducing alphaproteobacterium isolated from a bioelectrical reactor. Appl Environ Microbiol. 2010;76:4730-7.
45. Thrash JC, Pollock J, Torok T, Coates JD. Description of the novel perchlorate-reducing bacteria Dechlorobacter hydrogenophilus gen. nov., sp. nov. and Propionivibrio militaris, sp. nov. Appl Microbiol Biotechnol. 2010b;86:335-43.

46. Youngblut MD, Tsai CL, Clark IC, Carlson HK, Maglaqui AP, Gau-Pan PS, et al. Perchlorate reductase is distinguished by active site aromatic gate residues. J Biol Chem. 2016a;291:9190-202.

47. Carlström CI, Lucas LN, Rohde RA, Haratian A, Engelbrektson AL, Coates JD. Characterization of an anaerobic marine microbial community exposed to combined fluxes of perchlorate and salinity. Appl Microbiol Biotechnol. 2016;1-14.

48. Joshi N, Fass J. Sickle: a sliding-window, adaptive, quality-based trimming tool for FastQ files (Version 1.33) [Software]. 2011.

49. Simpson JT, Durbin R. Efficient de novo assembly of large genomes using compressed data structures. Genome Res. 2012;549-56.

50. Li D, Liu C-M, Luo R, Sadakane K, Lam T-W. MEGAHIT: an ultra-fast single-node solution for large and complex metagenomics assembly via succinct de Bruijn graph. Bioinformatics. 2015;31:btv033.

51. Li H. Aligning sequence reads, clone sequences and assembly contigs with BWA-MEM. 2013. Preprint at https://arxiv.org/abs/ 1303.3997.

52. Eren AM, Esen ÖC, Quince C, Vineis JH, Morrison HG, Sogin ML, et al. Anvi'o: an advanced analysis and visualization platform for 'omics data. PeerJ. 2015;3:e1319.

53. Wick RR, Schultz MB, Zobel J, Holt KE. Bandage: interactive visualization of de novo genome assemblies. Bioinformatics. 2015;31:3350-2.

54. Parks DH, Imelfort M, Skennerton CT, Hugenholtz P, Tyson GW. CheckM: assessing the quality of microbial genomes recovered from isolates, single cells, and metagenomes. Genome Res. 2015;114:gr.186072.186114.

55. Seemann T. Prokka: Rapid prokaryotic genome annotation. Bioinformatics. 2014;30:2068-9.

56. Finn RD, Clements J, Arndt W, Miller BL, Wheeler TJ, Schreiber F, et al. HMMER web server: 2015 update. Nucleic Acids Research: 2015;1-9.

57. Coates JD, Lonergan DJ, Philips EJP, Jenter H, Lovley DR. Desulfuromonas palmitatis sp. nov., a marine dissimilatory $\mathrm{Fe}$ (III) reducer that can oxidize long-chain fatty acids. Arch Microbiol. 1995;164:406-13.

58. Camacho C, Coulouris G, Avagyan V, Ma N, Papadopoulos J, Bealer K, et al. BLAST plus: architecture and applications. BMC Bioinforma. 2009;10:421.

59. Callahan BJ, McMurdie PJ, Rosen MJ, Han AW, Johnson AJA, Holmes SP. DADA2: High-resolution sample inference from Illumina amplicon data. Nat Methods. 2016;13:581.

60. Callahan BJ, McMurdie PJ, Holmes SP. Exact sequence variants should replace operational taxonomic units in marker-gene data analysis. ISME J. 2017;11:2639.

61. Tang JY, Riley WJ. A total quasi-steady-state formulation of substrate uptake kinetics in complex networks and an example application to microbial litter decomposition. Biogeosciences. 2013;10:8329-51.

62. Rittmann BE, McCarty PL. Environmental biotechnology: principles and applications. McGraw-Hill Education - Europe. 2001. ISBN-13: 2001;978-0071181846.

63. Thrash JC, Ahmadi S, Torok T, Coates JD, Division ES, Orlando E, et al. Magnetospirillum bellicus sp. nov., a novel dissimilatory perchlorate-reducing alphaproteobacterium isolated from a bioelectrical reactor. Appl Environ Microbiol. 2010a;76:4730-7.

64. Dubois JL. O-O bond formation by a heme protein: the unexpected efficiency of chlorite dismutase. molecular water oxidation catalysis: a key topic for new sustainable energy conversion schemes. In: Llobet (ed.). Molecular Water Oxidation Catalysis: A 
Key Topic for New Sustainable Energy Conversion Schemes. John Wiley \& Sons - United Kingdom. 2014.

65. Celis AI, Geeraerts Z, Ngmenterebo D, Machovina MM, Kurker $\mathrm{RC}$, Rajakumar K, et al. A dimeric chlorite dismutase exhibits $\mathrm{O}_{2-}$ generating activity and acts as a chlorite antioxidant in Klebsiella pneumoniae MGH 78578. Biochemistry. 2015;54:434-46.

66. Engelbrektson A, Hubbard CG, Tom LM, Boussina A, Jin YT, Wong $\mathrm{H}$, et al. Inhibition of microbial sulfate reduction in a flowthrough column system by (per)chlorate treatment. Front Microbiol. 2014;5:1-11.

67. Brundrett M, Yan W, Velazquez MC, Rao B, Jackson WA. Abiotic reduction of chlorate by $\mathrm{Fe}(\mathrm{II})$ minerals: implications for occurrence and transformation of oxy-chlorine species on earth and mars. ACS Earth Space Chem. 2019;3:700-10.

68. Stepanov VG, Xiao Y, Tran Q, Rojas M, Willson RC, Fofanov Y, et al. The presence of nitrate dramatically changed the predominant microbial community in perchlorate degrading cultures under saline conditions. BMC Microbiol. 2014;14:225.

69. Martens-Habbena W, Berube PM, Urakawa H, De La Torre JR, Stahl DA. Ammonia oxidation kinetics determine niche separation of nitrifying Archaea and Bacteria. Nature. 2009;461:976-9.

70. Daims H, Lebedeva EV, Pjevac P, Han P, Herbold C, Albertsen $\mathrm{M}$, et al. Complete nitrification by Nitrospira bacteria. Nature. 2015;528:504-9. 